Sign Systems Studies 30.1, 2002

\title{
Where bonds become binds: The necessity for Bateson's interactive perspective in biosemiotics
}

\author{
Peter Harries-Jones \\ Department of Anthropology, York University, \\ Ontario, M3J 1P3, Canada \\ e-mail: peterhj@yorku.ca
}

\begin{abstract}
The paper examines important discrepancies between major figures influencing the intellectual development of biosemiotics. It takes its perspective from the work of Gregory Bateson. Unlike C. S. Peirce and J. von Uexküll, Bateson begins with a strong notion of interaction. His early writings were about reciprocity and social exchange, a common topic among anthropologists of the time, but Bateson's approach was unique. He developed the notion of meta-patterns of exchange, and of the "abduction" of these metapatterns to a variety of other phenomena, in both biology and in game theory. Later, Bateson's concept of ecology of mind, the product of interactive phenomena, was modified by a non-purposive cybernetics. Biosemiotics has yet to adopt Bateson's interactive stance, which is absent from Peirce's approach to communication, of Uexküll's functional cycles, and of Hoffmeyer's discussion of the relation between culture and environment. Rather than pursuing notions of appropriate "subjectivity" through changed ethical response to ecological conditions (Hoffmeyer's discussion of empathy), the paper discusses the advantages of an approach that continues to focus on conditions of paradox and pathology. Specifically, Bateson's resolution of the relation between culture and environment arises from situations of blocked communication where ecological bonds become binds.
\end{abstract}




\section{Introduction}

The central importance of Gregory Bateson's ideas to the new biosemiotics, specifically to the writings of Claus Emmeche and Jesper Hoffmeyer cannot be disputed. The following concepts in the writing of Emmeche and Hoffmeyer are references directly drawn from Bateson: the conceptualization of difference as a "difference that makes a difference"; the refutation of mind and body as Cartesian duals in which "mind" lies in a hierarchical and therefore superior position to "body"; code duality, a distinction between analogue and digital coding in which analogue coding cannot be reduced to digital coding and vice versa; the importance of this for a better understanding of adaptation, as currently - orthodox neo-Darwinian molecular biology - conflates the two and attributes them holus-bolus to the activity of "the gene"; the notion of consciousness as a switch; the importance of disentangling notions of consciousness and human intentionality from a framework of control, specifically control over the environment; the notion of "the pattern which connects" as a methodological and epistemological project which overcomes the gap between culture and environment; the role that inter-subjective play among animals, and hence prototypical instances of "deceit" and "trust", has for our understanding of the origins of the linguistic distinction "not" (rather than the conventional notion that bodily gestures generated this communicative distinction). Emmeche has remarked that Bateson emerges as a "full-blown semiotician" (Emmeche 1999: 291n).

As a source of inspiration for the new biosemiotics and ecosemiotics, Bateson takes his place alongside C. S. Peirce and J. von Uexküll. Unlike the latter, Bateson begins his analysis from a different starting point, that of interaction rather than "subjectivity". As this paper will explain, Bateson's starting point is crucial if and when biosemiotics (and/or ecosemiotics) begins to include aspects of social relationship within the "life of signs" and must do so when it engages the issues of culture and environment. Culture embodies not only signs but signifiers and interpreters in relation to each other. So far discussion of this aspect of culture in biosemiotics has been minimal. 


\section{Communication: Inter-subjectivity and monologue}

Neither Peirce nor Uexküll rejected an inter-subjective perspective. Indeed, the later writing of C. S. Peirce took up inter-subjective themes and as Oehler remarks Peirce's tendency to conceive "subjectivity" inter-subjectively gets stronger towards the end of his life (Oehler 1987: 11). Nevertheless, Peirce reached his concept of signification initially as a result of a phenomenological analysis of the dialogue situation. Thus the communicative process and distribution of relations between speaker and hearer were marked as if signification in communicative activity followed from conversational dialogue with oneself. While Peirce is able to transform Kant's "transcendental subjectivity" to intentions of a speaker in actual communicative situations, he did not analyze communicative situation itself in terms of social variance of speakers. Peirce' theories of reality assumed ideal communicative groups. As a result the translation of Peirce from philosophical discourse to social discourse is difficult and requires commentators bold enough to re-align Peirce's vocabulary in order to bring it into sufficient correspondence with more sociological thinkers. One interesting attempt is made by Wiley who, in conjoining Peirce with his contemporary, George Herbert Mead, expands upon an implicit notion of "I" in Peirce's writing and translates it as the subjective "self" in order to place it in relation to G. H. Mead's thoroughly social conception of "me" as the self-in-society (Wiley 1994).

J. von Uexküll's writing is further removed from social processes. In fact he confines his writing to cellular and inter-cellular sign systems, on the one hand, and sign systems in which animals in their environment appear as "meaning-utilizers of meaning carriers in their environment" (T. von Uexküll 1987: 175). He thought of biological sign systems as "natural codes" which, unlike culture specific codes, were "innate". If culture specific situations were dialogical, biological sign processes were based on "monologue". Uexküll's discussion of functional cycles demonstrates what he means by 'monologue' for using sender-receiver terminology - the receiving function and the function of transmitting came together in such a way in a "functional cycle" that the biophysical receptors of an organism are "receivers", while the operative biophysical effector following such "reception" are "transmitters". There is, therefore no dialogue between senders and receivers in "functional cycles", and no self-reflexiveness during 
sending and reception. As T. von Uexküll states, the system or class of signs which a human observes and talks about is therefore very different to, perhaps in opposition to, the class of signs of the organism under observation.

As with many biologists, J. von Uexküll believed that the prototype of sociality among human groups was language. And while the use of language is clearly inter-subjective, nevertheless "the schemata (private character of signs) which we have formed during our life are inter-subjectively identical only in the most general outlines" (T. von Uexküll 1987: 161). Hence J. von Uexküll proceeds to investigate private character of "the exchange of signs", schema in "a subjective universe" both among humans and more particularly between humans and animals. Biosemiotics is urged to continue to examine the "subjectivity" of organisms in relation to environment. Thus:

In order to make the concept of semiotics valuable for both biology and medicine we must examine what it means [to undertake an examination of how] all signs that can be exchanged between living systems as well as between these and their surroundings... the signs that an observer of life systems registers are in the first place signs with which he interprets the events he himself has observed. However since the living systems he has observed are themselves interpreting their own surrounding, he must interpret their interpretations whereby these systems decipher their environment [...] We must, as meta-interpreters, try to reconstruct the interpretation that points the way for the paramecium in its surroundings. (T. von Uexküll 1999: 650-651)

Nevertheless, meta-interpreters of living systems derive a large proportion of their perceptions and cognition from the social world of which they are a part. Biological scientists today, even of paramecium in their surroundings have a hard task convincing their public that their observations are entirely "value free".

\section{Bateson's interactive stance}

While some sociologists, especially in the period 1920-1940 looked for the prototype of human sociality in language, the tradition of sociology, certainly of anthropology, is heavily weighted towards the proposition that the roots of human sociality are to be found in social acts rather than languaging. The social enactment of signification, 
rather than the mere ability to signify provides the rudiments of "bonding" in social exchange. Bateson follows this trend though much of his later writing about human sociality provides a study of the adverse effects of "bonding", the "double bind" that can lie within social bonds, and binds in ecological interactions as well. The differences between Bateson and Uexküll on the issue of the "subjectivity" of the organism, and of the position of observers reporting upon "subjectivity" and "feedback" are therefore important.

As an interactionist Bateson argued that "Mind", subject, self, as with the many forms of subjectivity and individuality so pervasive in western scientific thinking, was not "in" the head, but always derived from the interactions of self with other and self with system. And this understanding must be fundamental to participatory observation, whether of humans or of animals or of the human-animal world. With regard to any issue of intelligence and observation, Bateson, consistently wrote against the idea of a single located space of explanation. He thought that such a framework of explanation always to led to error. In the realm of human beings, many of the problems in approaching mind and self in sociology, anthropology and linguistics arose from the way each discipline presumed that the internal mind of individual selves was a starting and ending point for their investigation. The same was true of animal intelligence. Uexküll is evidently no exception to discussing animal intelligence, perception and communication from the vantage point of the individual organism. Perhaps this is why Bateson does not refer to him in his own writing, though he must have known of Uexküll's opposition to Darwinian interpretations of evolution. Bateson's own method was of double description and never that of single description, that Newtonian dimension which always located "self" or "mind" in a single space. For Bateson mind is "no-thing". It is empty. It exists only in its ideas and these again are no-things. And an idea is what mind makes of it, in its communicative interactions, namely an example of something or other (Bateson 1978: 9).

Bateson always started analyses with interaction between individuals, and never with the single individual. The unit of analysis, reciprocal communicative interaction, belonged to neither individuals per se but rather reflecting rules of relationship between the communicating partners. Senders and receivers were, of course, connected in some physical manner to each other, for all communication requires a 
material carrier, but the communicative content drawn from physical connection was at another, less important level of meaning than that drawn from the rules of the relationship existing between the communicators. ${ }^{1}$ Among humans, any messages must be interpreted primarily from the rules of the relationship existing between individuals; in the animal world this included such phenomenon as predator and prey, a "dog chasing a hare".

There are, perhaps, three periods of his investigation of intersubjective interactions. In each period Bateson tended to look not only at single interactions but at patterns of interactions and meta-patterns of those interactions in a dynamic context. In other words from the beginning of his career in the 1920s Bateson developed a meta-level focus in his discussion of social interactions. This was most unusual in social psychology and of anthropology both of which continued from the 1920s to the 1970s to derive explanation from empirical data of observed interactions, mostly through small group research or ethnographic study of small communities. Kurt Lewin's field theory of social psychology, to which Bateson was attached during the 1940s and 1950s, was an exception. In their studies of community, social anthropologists re-constructed empirical observations of ritual acts involving, for example, sacrifice of animals and plants. It was within this re-written "structure" of social relations, the anthropologists depiction of ordered relations that individual observations of ritual acts took on an overall coherence as a belief system.

In Bateson's Australasian period of fieldwork, that is to say his research prior to World War II, Bateson looked at aspects of reciprocity or gift exchange in the middle part of the Sepik River of New Guinea. He argued that patterns in gift giving ought not originate from direct observation of individual gift giving per se, but from a more dynamic aspect in which variance in the cycles of cumulative interactions the main focus. He argued that observed reactions of

${ }^{1}$ Bateson even believed that symbolic interactionists like George Herbert Mead who investigated the meaning of symbols told only half a story of the relation between social action and communicative reflexivity. G. H. Mead's concept of roles and roletaking did indeed describe a social "reaction of reaction", but Mead never considered a meta-patterning of the dynamics of exchange in role-taking, which would have resulted in the investigation of "I know that you in your role are taking account of me in my role" allied to analysis of the rules of the relationship i.e. "what are the social conditions of role-taking in the first place?" Bateson and his colleagues at Palo Alto undertook such analyses. 
villagers to a receipt of a gift, yielded information about "the reaction of reactions" to gift giving. Rather than reporting a simple empirical outcome of how individuals engaged in acts of exchange vis-à-vis one another, an anthropologist should concentrate on how these "reactions to reactions" generate exchange cycles. In turn, this leads to a consideration of the changes which cumulative interaction brings about within exchange cycles.

Thus, long before postmodernism, Bateson was arguing that the dynamics of such exchange cycles would only become apparent through a "reflexive take" on empirical fieldwork data. As the observer's reflexive take shifts to the dynamics of interaction and its characteristic cycles, the patterns of interactive dynamics in the cycle of exchange would reveal evidence that empirical treatment of data would ignore, possible runaway effects of cumulative interactions, for example. Bateson termed this study of meta-patterns of exchange "schismogenesis", for, at the point that runaway occurs, initial patterns of reciprocity become transformed into vicious circles and are brokenup. He argued there were cultural preferences for particular interaction sequences, hence cultural preference enters into particular forms of runaway, unless that culture enacts procedural rules to prevent the occurrence of vicious circles (Rogers 1981: 235ff). In addition, he argued that there was cultural preference for particular forms of interactive sequences between individuals and/or groups which prevented runaway effects and that this pattern of cultural preference was a striking outcome of the embeddedness of interaction sequences in cultural relationships. He presented a comparative case study based on his research in New Guinea and in Bali.

His meta-pattern perspective permitted Bateson to pursue the notion of the "universality" of reciprocity or exchange in a very different manner from other anthropologists. Instead of writing about the universality of reciprocity and the way a common underlying structure of reciprocal exchange enters into all types of human social relations, he began to "abduct" his investigation of cumulative interactions of "reciprocity" in a variety of contexts, such as comparing gift-giving with the diplomacy of armaments races. Later these included studies of cumulative interactions in game theory, the prisoner's dilemma for example, and in families who have one member diagnosed as schizophrenic. 
During his years elaborating cybernetic thinking, 1945-68, Bateson discussed interaction in cybernetic control systems, where oscillations produced not only runaway but also an alternative phase, that of the dampening down of feedback cycles. The pattern of binds in reciprocal exchange that needed to be studied Bateson noted, emerged from an understanding of the sort of oscillation that metapatterns of interactivity displayed. He also enlarged upon his key concept that phenomena which people believe occurs inside the head, are part of a broader pattern of communicative interactions that includes social relations between people. Important meanings arose recursively, in feedback between individuals and those with whom they had intimate social relationships. Always a description of the "reflexive take" of people in interaction was required, before meaning could be interpreted in any communicative setting. The other important feature was that such descriptions of "reflexive take" should occur at various levels of interaction, one mapping upon another, so, for example, evidence about the injunctive or normative aspects of social relationships between people which gave overall context to their communication should be placed against evidence about the content of signification: metaphor, imagination etc. ${ }^{2}$

In the last ten years of his life Bateson carried these ideas forward into his "ecology of mind", his most lasting contribution. An ecology of mind requires that we must come to an understanding of living systems as part of own life-process, while at the same time recognizing that our own self-hood is part of that larger whole. Clearly this cannot be accomplished through so simple a method of description as describing as series of "needs" in a located space. Indeed, Bateson's initial objections to the methodology of one of the founding fathers of anthropology, Bronislaw Malinowski, was that Malinowski, in arguing about human social exchange, reduced "the social" in social activity to the biology of "needs", and Malinowski's depiction of "functional cycles" elaborated upon this reductionism. ${ }^{3}$ I do not know

${ }^{2}$ Much of the way in which Bateson revised cybernetics cognitive modeling of "control" as an aspect of located information is covered in my own book A Recursive Vision: Ecological Understanding and Gregory Bateson (Harries-Jones 1995) and in the book by Steve Heims, The Cybernetics Group (Heims 1991). Hoffmeyer also refers to Bateson's objections to control assumptions.

3 Objections among anthropologists to Malinowski's "functionalism" a theory
3 . which proposed, inter alia, that all significant phases of cultural activity could be seen as an expansion of the biology of needs was widespread even before World War II. 
of any Bateson reference to the "functional cycles" of J. von Uexküll, but it is reasonable to assume that his same objections would hold.

\section{Ecology of mind}

Because of the inherently social nature of communication, it is possible to step outside of the content of inter-subjective communicative interactions and adopt a mode of interpretation that is logically above, or "meta" to the events initiating the communication. In other words, it is possible to discuss human communication at the level of the rules about responses to messages, and even discuss meta- patterns of messages among communicants. This may be difficult, but family therapists following in the footsteps of Gregory Bateson accomplish this all the time, clarifying how inappropriate pattern and rules of communication create disturbance in meaning among the communicators. The problems of interpreting meta-communicative patterns in ecological situations are far more difficult. The rules of humanenvironment exchange are very uncertain, so strictly speaking there can be no "meta" "meta" perspective, in the sense of a perspective derived from "above" immanent conditions of exchange in humanenvironment relations. This, perhaps is a reason for so many cultures adopting a transcendental spiritual rather than immanent ecological perspective of their relations to their environmental surround.

Comprehending the ecology of living systems, requires, even more definitively than the study of communicative interaction among human beings, a concerted focus on both the difficulties and the possibilities of reflexive interaction with "nature". In one of Bateson's most amenable articles, "The pattern which connects", his sophisticated approach invokes all manner of interpretative forms at various

Subsequently the criticism entered into introductory texts in anthropology. Bateson was always careful to be as positive as he could about Malinowski's achievements in published articles. In his private correspondence Bateson was scathing. An interesting exchange about Malinowski is contained in the correspondence he had with Meyer Fortes, and Bronislaw Malinowski himself, in and around November, 1935 [SPEAMargaret Mead Collection, Library of Congress, Bateson Correspondence Box 01]. It is also of interest that Bateson's primary objection to Karl Marx was that Marxian political theory built itself upon a premise of human needs. The concept of "needs" as an explanatory premise, Bateson would argue later, introduced a confusion in logical types i.e. it was an abstract generality which required contextual unravelling. 
levels of perception that might aid us to develop meta-perspectives: logical distinctions, aesthetic appreciation and their embodiments shapes, forms and relations in their symmetries and in their modulation. There are always empirically observed connections in the morphology of a living creature, he reminds us, always patterns of bilateral symmetry and serial homology within a growing organism which can be readily observed The pattern which connects the crab to the lobster, the orchid to the primrose, me to you, are less obvious, for the pattern which connects these embodiments to each other are metaorder connections, based on similar relations between parts and their interaction within some ecosystemic whole. Finally there is a third level, meta-meta-connection (not to be confused with Peirce's notion of Thirdness) which is even more difficult to grasp. Here a comparison between the interaction of crabs and lobster must be compared with the comparison between men and horses, and all of us to the amoeba. It is these sorts of third level patterns of connection that we must try to grasp in the understanding of how humanity fits its own idea of self-hood into a larger whole of interactive interconnection of living systems. The question is not simply one of meta-interpretation of homologies in organisms but a comparison of patterns of patterns of interactive similarities and differences. "The pattern which connects is a meta-pattern. It is a pattern of patterns. It is that meta-pattern which defined the vast generalization that indeed it is patterns which connect" (Bateson 1978: 9).

In his final years of writing Bateson addressed himself to the topic of how we should develop a recursive epistemology able to think about such interconnections. In one of very his last papers Bateson pursues this point with regard to the differences between the logic in syllogism, that is the logic of empirical science, and tautology in nature. The latter he terms the logic of Barbara, and invokes the phrase "men are grass" in order to explore the tautology, i.e., tautology in the sense of mutual connectedness. He explores the metaphorical sense, juxtaposition of signs in the Barbara tautology, but behind the metaphor "men are grass" Bateson invites us to look at ecological circumstance. Humanity adapts to, and alters grass, through human agricultural practices. In fact the most cursory research reveals that the "men-grass" bond has been fundamental in the evolution of human beings and history of cultures. A broad ecological view of this pattern is that grasses have domesticated our species. As a con- 
sequence of species domestication the grasses are among the most successful organisms on Earth. The most productive plants for human beings have been those with edible seeds - grasses such as corn, wheat, rice and barley. Today cereal grains provide some two third's of humanity's intake, directly and through grain fed livestock, and occupy about half of the world's arable land. Yet modern crops are utterly dependent on a human agricultural infrastructure that feeds and waters them, protects them from pests and looks after their germ plasm (Bright 1998: 35-36). Successful bonds yield enormous mutual benefit, yet as Bateson points out, these very same bonds can also lead to relational dilemmas, both in human beings and in the natural world. Misunderstanding the significance of reciprocities in exchange and their mutual causality can threaten survival.

\section{Culture and environment: The Hoffmeyer triangle}

In his organizing diagram in Signs of Meaning Hoffmeyer seeks to untie western dualistic approaches to three fields of inquiry (Figure 1). The first approach is that of psycho-somatic dualism — duals raised in cognitive science and elsewhere that separate mind and body, mental activity from bodily activity. The second field of inquiry he unties is that of biology and semiotics, the dualism arising because biology predicates its analyses on the overwhelming determinism of inner nature, while one aspect of inner nature, the capacity to communicate, has come to be analysed in another discipline through "external" investigation of "languaging" and/or signification. Hence a prevailing dualism between inner nature and outer nature. The third field of inquiry he discusses is the dualism between culture and environment. Here Hoffmeyer argues that ecologists keep on splitting the world up into two distinct sectors, the natural and the cultural, thereby upholding several illusions that alienate human beings from nature (Hoffmeyer 1996: 43). He seeks to repair this dualism through an analogical extension of "subjectivity" in so far as the capacity for "subjectivity" in human culture can lead both to "empathy" for animals and other living organisms, and that empathy is in turn linked to the "ethical status" of animals and other living forms. The ethical debate within human culture is essential, Hoffmeyer states, in order to 
keep reviving "our existential need to empathize with other umwelt builders in this weird and wonderful world" (Hoffmeyer 1996: 141)

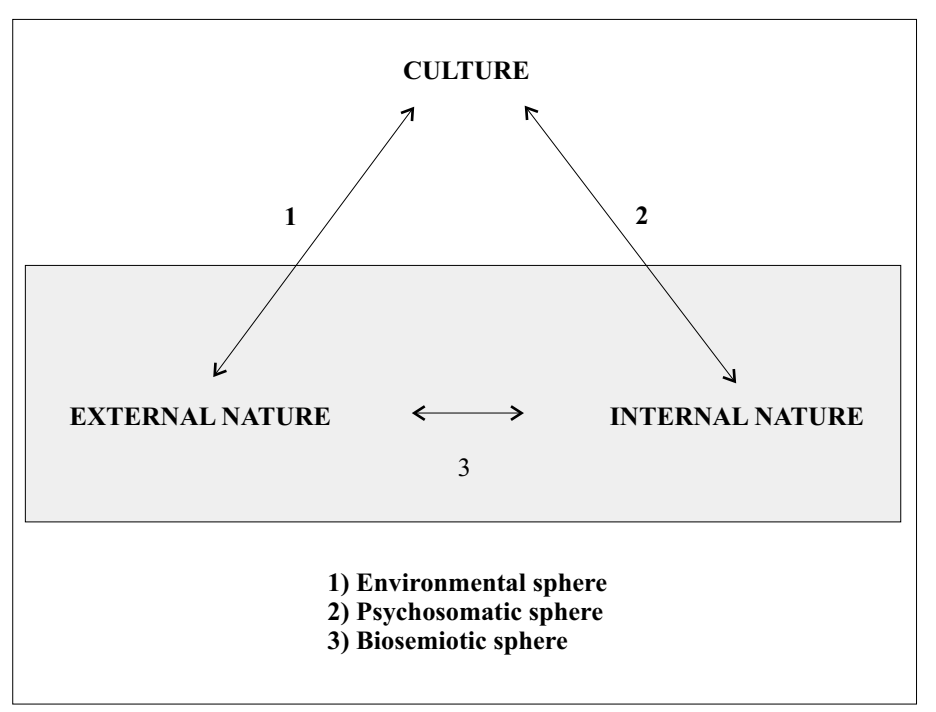

Figure 1. Hoffmeyer's "Lost Connection", or how biosemiotics mediates between humanity's outer and inner nature and between culture and nature (from Hoffmeyer 1996: 96).

The dualism Hoffmeyer seeks to overcome lacks the congruence of his other two cases. There are both differences in respective time periods of cultural formation and of formation of environmental conditions, and in their respective oscillation and rates of change. Hoffmeyer acknowledges that the operational aspects of memory, learning and forgetting are far more plastic in the realm of culture as a result of language - than they are in the biophysical environmental realm of evolution, and that the patterning of code-duality in the two instances is therefore, not the same. There is a difference, yet the difference between the two does not yield a dualism. ${ }^{4}$ The crux of

${ }^{4}$ As I report in my own book, Bateson noted there were differences between culture and its evolutionary environment in that the level of genetic constraint in evolution had no parallel in culture. While genetic adaptations can affect levels of 
Hoffmeyer's argument is that though our individual life stories become divorced from our genetic history, "Not one but two stories are being enacted in the human body and consciousness" at the same time (Hoffmeyer 1996: 133; italics in original).

To support his argument, Hoffmeyer discusses how evolutionary growth of language and self-consciousness in Homo sapiens has enabled human beings to break out of their own subjectivity and enabled them to share one large common Umwelt. He observes in the passage cited above how the common bond of speech increased the capacity of humans to empathize with animals and other living species and prepare humanity for the current "ethical drama of the human race". He calls for a profusion of semiotic niches in which humans relate to the "subjectivity" of other living creatures. In an earlier passage he states that "The spoken word has endowed the semiosphere with its very own self-referential vertical semiotic system [to complement horizontal semiosis of interconnections]. A new code duality has emerged and with it the dynamic basis for a totally different kind of evolution: cultural history" (Hoffmeyer 1996: 112). The problem is that Hoffmeyer talks here and elsewhere of "culture" and cultural history in a universal sense, though concepts examined are really a presentation of European cultural premises, specifically the premises of western science. Evolutionary appraisal of his key notions, "subjectivity" and "human empathy" is especially prominent, following a tactic frequently used by western science (until recently by western anthropology as well) in order to depict the existence of cultural predisposition. There is no need to evoke evolutionary sequences to investigate inter-subjectivity towards nature. There are many cultural examples open for inspection and which give detailed evidence as to how humans develop empathy towards nature. The conundrum is that such cultural examples are supported by traditional ecological knowledge and not supported by western scientific knowledge.

levels of constraint among populations, culture "has no level of control between individual learning and the level of population". Culture cannot alter the homoeostatic bias of individual learning in the manner that genetic control at population level can alter the homeostat of the phenotype (Harries-Jones: 1995: 258). Among other things, lack of such constraints feeds potential for runaway in learned ideas. Perhaps we could add to this distinction by noting that while genetic constraints operate through the process of division and replication of an unbound state, the expansion and contraction of ideas evoked in a reflexive process is somewhat different from genetic conservation or mutation. 
A good place to start is with the Australian Aborigines. Here there are a profusion of semiotic niches in which humans relate to the "subjectivity" of other living creatures all the way from interpretations of the Dreaming to anecdotal stories drawn from the lives of individuals (Rose 2000). Among the Yarralin, a band of Australian Aborigines, human beings are indeed regarded as being close to other placental mammals. It is dingo, the Australian wild dog, that is taken to be the true marker of the boundary between humans and other living creatures, or "what humanity would be if humans were not what we are". The reason given for their cultural preference for dingo is that humans are like no other animals in so far as the shape of their genitals is concerned. Clearly humans are not like Australian marsupials. Male kangaroos have their testicles and penis back to front from a humans perspective. Female kangaroos also have a pouch, human females do not.

Rose brilliant and sensitive account of the Yarralin centres around how Yarralin form their knowledge of boundaries between humanity and other living systems. Yarralin feel that they interpret very differently from the way that white Australians interpret the same evidence. And indeed they do. In the case of Yarralin, knowledge is indeterminate, it is not immediately gained through experimentation, and always subject to contextual revision in discussion among members of a social unit. The process of determining meaning is one of testing many meanings in a seeming free-for-all until some form of consensus is reached in the social unit and then "it is finished". There is redundancy to account for and there are countless reciprocities to pay attention to and interpret. Moreover 'just as other beings' actions elicit response from human beings, so also human actions elicit responses from other beings [...][Yarralin believe] other species are watching us, reacting and responding" (Rose, 2000: 228) ${ }^{5}$.

${ }^{5}$ Rose's evidence is a clear break with Hoffmeyer's arguments about human Umwelt exhibiting graded "subjectivity". Hoffmeyer's thesis is that "The more anthropoid its [the character of the animal's] umwelt, the greater our empathy with it" (Hoffmeyer 1996: 140). Animal characteristics, behaviour and anatomy are rarely graded outside European cultures the way they are within it. Ours tend to follow the Linnaean categorization. As the Yarralin show, other cultures give animals and the living world very different symbolic qualities and shapes than those which European cultures perceive. Before we became human, the Yarralin say, we had genitals like dogs: "Women had a vulva stuck out the back and men had a penis that was attached up the belly, and when they mated they became stuck together the way that dogs do 
Rose's evidence for Yarralin belief and the dynamics of their knowledge system is strongly related to Yarralin social interaction. She argues that in a total cultural system, its "totality" created by the social boundaries between white Australians and black Aborigines. Testing the veracity of events occurs and fades away within the dynamic interplay of communication and interpretation among Yarralin themselves. In this respect, nothing external is drawn into to the local culture or its knowledge system, though as a result of this social rejection of the external Aboriginal knowledge survives.

The knowledge system of western ecologists is also characterized by an inward looking social circle. As Bateson argued, any change in cultural ideas requires breaking, or reform of, social bonds in addition to a shift in levels of semiotic interpretation. Social bonds, not primary biological dispositions such as the capacity for sympathy and language, are the primary injunctive for human beings and social bonding cannot be abstracted from belief preference and appraisal of knowledge. The dominant idea discussed in Bateson's "The cybernetics of self" (Bateson 2000: 309-337) is that the "self" must be conjoined within a different social grouping in order to achieve a different epistemology. Bateson pointed out that the paradoxes of life from which extrication is so difficult always lead back to binds of relationships.

In his discussion of ecosystems, he suggests how modern day science alters the reciprocal bonds between humanity and nature in such a way that science drives nature mad. His example was the "death" of Lake Eire and the case of the St.Clair River next to Detroit spontaneously bursting into flames in the 1960s. Rather than consider how "empathy" for environment might relate in such a case to an individual's stance on his or her ethical responsibilities for environment, Bateson's resolution was to foster understanding of recursive epistemology, and of the dynamic interaction where bonds become binds. His premise was that faulty human thinking about nature will always return to stab humanity in the back. Therefore our primary methodology should be that of the uncovering of non-awareness of recursion in human-nature bonds and a further understanding of how

[...] people used to get stuck together for days, even weeks. The dingo called in [... people used to get stuck together for days, even weeks. The dingo called in
'doctors' to fix us up. The bat cut a new vulva, and put a mussel there to keep it from closing up again. Bower bird (Chlamydera nuchalis) was the doctor for the men. He put the penis at the proper place and positioned the testicles correctly" (Rose 2000: 48). 
this state of affairs locks - in cumulative errors of interpretation. A grappling with paradoxes, as they emerge, should be a primary means through which we investigate this problem. Since Bateson's death the paradox of "sustainable development" has provided an empirical example.

\section{Conclusion}

This paper has considered various aspects of Bateson's work and shown how they are predicated upon interaction rather than "subjectivity". In his early work, his examination of patterns in gift giving in human exchange lead him to an understanding of cumulative interactions within exchange cycles, which in turn revealed the presence of vicious circles and the presence or absence of feedback. Though Bateson borrowed from C. S. Peirce, particularly Peirce's methodology of abduction, he did not endorse Peirce's pragmatics, almost certainly because of the phenomenological framework of Peirce's methodology. In addition, while Bateson clearly supported Peirce's triadic logic, Peirce's discussion of the dialogical in communicative situations was, to a large extent, monological. Without understanding feedback properties at different levels, the one "meta-" to the other, Bateson believed one could not explain social dilemmas that arise in learning and other aspects of communication.

The type of feedback prevalent in J. von Uexküll's discussion of "functional cycles" is also monological rather than interactive. Uexküll's concept of Umwelt has been open to different sorts of interpretation. One argument is that "no animal ever takes up the role of an observer" (T. von Uexküll 1987: 162). Objects in the animal world are "only objects on which they are dependent as a result of biological needs (e.g. hunger) and which disappear from their surrounding world as soon as the need has passed". If so, then the operation of functional cycles must also be of a categorically different type of feedback than those predicated on the information principles of cybernetics. Another argument supporting J. von Uexküll is that animals are indeed "cognitive observers". One interpreter suggests J. von Uexküll's depiction of the relation of organism (as subject) to environment is in the form of a hermeneutic circle. A relationship of complementarity is struck between the Umwelt and the inner world of 
the organism through the organism's ability to form a "cognitive model" of its Umwelt, or, to use Uexküll's expression, there is a counter-structure between the organism and its environment as carrier and receiver of meaning (Nöth 1999). Bateson would not support either justification, the one because functional cycles are not cybernetic, the other because his own interactionist perspective categorically rejected hermeneutic interpretation.

In Bateson' terms, a bond is something beyond straightforward investigation of semiotic ties of a paramecium in its surroundings, or even of bonds identified through investigation of signs exchanged between organisms in living systems. Bateson emphasizes instances in which bonds have become binds, and these always involve mistakes in interaction. As Bateson argued, non-resolution of binds always threaten survival. For this reason I suggest that the link between culture and environment depicted in the third leg of Hoffmeyer's triangle of biosemiotic enquiry is best represented in the form of a Möbius strip. That is to say, there is a "twist" in the join between the two terms culture and environment and that this "twist" designates a series of paradoxes in cultural and environmental interaction, each of which sensitizes us to the cumulative non-resolution of mutual causal reciprocities. Finally, closing the dualism between culture and environment requires careful use of the concept of culture, and the use of empirical evidence drawn from "cultures" in the plural rather than a supposed universal "culture", since theories of knowledge are themselves culturally specific.

\section{References}

Bateson, Gregory 1978. The pattern which connects. CoEvolution Quarterly 18: 4-15.

- 2000 [1972]. Steps to an Ecology of Mind. Chicago: Univesity of Chicago Press.

Bright, Chris 1998. Life Out of Bounds: Bioinvasion in a Borderless World. New York: Norton for the Worldwatch Institute.

Emmeche, Claus 1999. The Sarkar challenge to biosemiotics: Is there any information in the cell. Semiotica 127(1/4): 273-293.

Harries-Jones, Peter 1995. A Recursive Vision: Ecological Understanding and Gregory Bateson. Toronto: University of Toronto Press.

Heims, Steve 1991. The Cybernetics Group. Cambridge: MIT Press. 
Hoffmeyer, Jesper 1996. Signs of Meaning in the Universe. (Trans. Barbara Haveland). Bloomington: Indiana University Press.

Nöth, Winfried 1999. Ecosemiotics and the semiotics of nature. In: Taborsky, Edwina (ed), Semiosis, Evolution, Energy: Towards a Reconceptualization of the Sign. Aachen: Shaker Verlag, 73-87.

Oehler, Klaus 1987. An outline of Peirce's semiotics. In: Krampen, Martin; Oehler, Klaus; Posner, Roland; Sebeok, Thomas A.; Uexküll, Thure von (eds.), Classics of Semiotics. New York: Plenum Press, 3-19.

Rogers, L. Edna 1981. Symmetry and complementarity: Evolution and evaluation of an idea. In: Wilder, Carol; Weakland, John (eds.), Rigor and Imagination: Essays from the Legacy of Gregory Bateson. New York: Praeger, 231-252.

Rose, Debbie B. 2000. Dingo Makes Us Human: Life and Land in an Australian Aboriginal Culture. Cambridge: Cambridge University Press.

Uexküll, Thure von 1987. Sign Theory of Jakob von Uexküll. In: Krampen, Martin; Oehler, Klaus; Posner, Roland; Sebeok, Thomas A.; Uexküll, Thure von (eds.), Classics of Semiotics. New York: Plenum Press, 147-179.

- 1999. The relationship between semiotics and mechanical models of explanation in the life sciences. Semiotica 127(1/4): 647-655.

Wiley, Norbert 1994. The Semiotic Self. Chicago: University of Chicago Press.

\section{Когда связи становятся связующими: о важности интерактивного взгляда Бейтсона для биосемиотики}

В статье подвергаются анализу различия в подходах разных авторитетов, чья интеллектуальная деятельность повлияля на развитие биосемиотики. При выборе точки зрения автор исходит из работ Грегори Бейтсона. В отличие от Пирса и Юкскюлля Бейтсон начинает с понятия интеракции. Его ранние работы касались взаиозависимости и коммуникации - центральных тем в работах тогдашних антропологов. Но подход Бейтсона все же выделялся своей уникальностью. Он создал теорию о метамоделях социальной коммуникации и об их “абдукции” в разные феномены как в биологии, так и в теории игр. Позже Бейтсон на базе концепции экологии духа (которая является выражением феномена интерактивности) разрабатывал нецелевую кибернетику. Биосемиотика еще не приняла интеракционный подход Бейтсона - он отсутствует в коммуникационных исследованиях Пирса, в функциональном круге Юкскюлля и в рассуждениях Хоффмейера об отношениях между культурой и природой. Вместо того, чтобы исходить из понятия “субъективности”, которая якобы возникает при изменении этического отношения в соответствии с экологической обстановкой (рассуждение Хоффмейера о эмпатии), статья выделяет подход, который сосредотачивается на состояниях пародокса и патологии. Точнее, точкой отталкивания при 
анализе отношений между культурой и природой у Бейтсона является состояние блокированной коммуникации, где экологические отношения становятся связуюшими.

\section{Kui seosed muutuvad siduvateks:}

\section{Batesoni interaktiivse vaate olulisusest biosemiootikale}

Artikkel analüüsib olulisi erinevusi nende autoriteetide seisukohtade vahel, kelle intellektuaalne tegevus on mõjutanud biosemiootika arengut. Vaatenurga valikul lähtutakse Gregory Batesoni töödest. Erinevalt C. S. Peirce’ist

ja J. von Uexküllist, alustab Bateson interaktsiooni mõistest. Ta varajased kirjutised puudutasid vastassõltuvust ja sotsiaalset kommunikatsiooni keskseid teemasid tolleaegsete antropoloogide hulgas — kuid Batesoni lähenemine oli siiski unikaalne. Ta lõi teooria sotsiaalse kommunikatsiooni metamustritest ja nende "abduktsioonist" mitmesugusteks teisteks fenomenideks nii bioloogias kui mänguteoorias. Hiljem arendas Batesoni kontseptsiooni vaimu ökoloogiast (mis on interaktiivsuse fenomeni väljenduseks) edasi teist järku küberneetika. Biosemiootika pole veel Batesoni interaktsioonilist lähtekohta omaks võtnud — see puudub nii Peirce kommunikatsioonikäsitluses, Uexkülli funktsiooniringis, kui ka Hoffmeyeri arutluses kultuuri ja looduse suhete üle. Selle asemel, et lähtuda kohase "subjektiivsuse" mõistest, mis tekkivat eetilise suhtumise muutumisel vastavaks ökoloogilisele olukorrale (Hoffmeyeri arutlus empaatiast), tõstab siinne artikkel esile lähenemist, mis jätkuvalt keskendub paradoksi ja patoloogia seisunditele. Täpsemalt, Batesoni lähtekohaks kultuuri ja looduse suhete analüüsimisel on blokeeritud kommunikatsiooni seisund, kus ökoloogilised seosed muutuvad siduvateks. 